\title{
HUBUNGAN PENGETAHUAN DAN MOTIVASI IBU TENTANG PEMBERIAN AIR SUSU IBU (ASI) EKSLUSIF DI KELURAHAN PALMERAH WILAYAH KERJA PUSKESMAS PAAL MERAH II KOTA JAMBI
}

\author{
Hesty \\ Program Studi D-III Keperawatan STIKes Baiturrahim Jambi \\ Email:hestywiqi@gmail.com
}

\begin{abstract}
Breast milk is the most perfect milk for children up to the age of two, and it is even advisable to give exclusive breastfeeding for the first six months, and it is recommended for breastfeeding colostrum when first breastmilking comes out. Breast milk is contained many antibodies that are good for the baby's immune. This research is a quantitative research by using prospective approach that is design by looking forward from an event that related to the occurrence of the research or incident that happened at the same time. The result showed that respondents with good knowledge in breastfeeding were 25 $(71,4 \%)$ of respondents. From Chi Square analysis results obtained p-value $=0.044$ $<0.05$, it can be concluded that there is a significant relationship between knowledge of mother with breastfeeding in Kelurahan Palmerah working area Puskesmas Paalmerah II Kota Jambi. From Chi Square analysis results obtained $p$-value $=0.046<0.05$, it can be concluded that there is a significant relationship between motivation with breastfeeding in Kelurahan Palmerah working area Puskesmas Paalmerah II Kota Jambi.
\end{abstract}

Keywords: Exclusive ASI, Knowledge, Motivation

\begin{abstract}
ABSTRAK
ASI merupakan susu yang paling sempurna untuk anak hingga usia dua tahun, bahkan sangat dianjurkan untuk memberikan ASI eksklusif selama enam bulan pertama, dan dianjurkan untuk pemberian ASI kolostrum saat pertama kali ASI keluar. ASI terkandung banyak antibodi yang baik untuk kekebalan tubuh bayi. Penelitian ini merupakan penelitian kuantitatif dengan menggunakan pendekatan prospective yaitu rancang bangun dengan melihat kedepan dari suatu kejadian yang berhubungan dengan kejadian yang diteliti atau kejadian yang terjadinya pada waktu yang bersamaan. Hasil penelitian diketahui bahwa responden dengan pengetahuan tinggi dalam pemberian ASI sebanyak $71,4 \%$ responden, $82,2 \%$ memiliki motivasi baik dalam pemberian ASI. Analisis statistik menunjukkan nilai p-value 0,044 dan 0,046 sehingga disimpulkan terdapat hubungan bermakna antara pengetahuan dan motivasi responden terhadap pemberian ASI.
\end{abstract}

Kata Kunci: ASI Ekslusif, Pengetahuan, Motivasi 


\section{PENDAHULUAN}

Air Susu Ibu (ASI) adalah kebutuhan cairan tanpa tanding ciptaan Allah untuk memenuhi kebutuhan gizi bayi dan melindunginya dalam melawan kemungkinan serangan penyakit keseimbangan zat-zat gizi dalam air susu ibu berada pada tingkat terbaik dan air susunya memiliki bentuk paling baik bagi tubuh bayi yang masih muda. Pada saat yang sama, ASI juga sangat kaya akan sari-sari makanan yang mempercepat pertumbuhan sel-sel otak dan perkembangan sistem saraf. ${ }^{1}$

ASI adalah suatu emulsi lemak dalam larutan protein, laktosa, dan garam organik yang disekresi oleh kedua kelenjar payudara ibu dan merupakan makanan terbaik untuk bayi. Selain memenuhi kebutuhan makanan bayi baik gizi, imunologi, atau lainya, pemberian ASI juga merupakan kesempatan bagi ibu untuk mencurahkan cinta kasih serta perlindungan kepada bayinya. Fungsi ini tidak mungkin dapat dialihkan kepada ayah (suami) dan merupakan suatu kelebihan kaum wanita. ${ }^{2}$

ASI merupakan susu yang paling sempurna untuk anak hingga usia dua tahun, bahkan sangat dianjurkan untuk memberikan ASI eksklusif selama enam bulan pertama, dan dianjurkan untuk pemberian ASI kolostrum saat pertama kali ASI keluar. ASI ini sangat baik, selain kandungannya yang mudah dicerna oleh bayi, dalam ASI ini terkandung banyak antibodi yang baik untuk kekebalan tubuh bayi. ${ }^{3}$

Kolostrum adalah cairan yang dihasilkan oleh kelenjar payudara setelah melahirkan (4-7 hari) yang berbeda karakteristik dan komposisinya dengan ASI matang atau cairan tahap pertama ASI yang dihasilkan selama masa kehamilan dan berakhir beberapa hari setalah kelahiran bayi (2-4 hari), berwarna kuning keemasan (Creamy) dengan volume $150-300 \mathrm{ml} / \mathrm{hri}$, serta lebih kental jika dibandingkan cairan susu pada tahap berikutnya. ${ }^{4}$

Pemberian Air Susu Ibu (ASI) sampai usia 6 bulan dapat mencegah kematian 1,3 juta anak berusia dibawah lima tahun. Penelitian di Ghana yang diterbitkan Jurnal Pediatries menunjukkan $16 \%$ kematian bayi dapat dicegah melalui pemberian ASI pada bayi sejak hari pertama kelahirannya. Angka ini naik menjadi 22\% jika pemberian ASI dimulai dalam satu jam pertama setelah kelahiran bayi ${ }^{5}$

Gencarnya promosi susu formula juga menjadi penyebab menurunnya jumlah bayi yang mendapatkan Air Susu Ibu (ASI), berdasarkan Survey Demografi dan Kesehatan Indonesia di tahun 2004 dan 2009, angka pemberian ASI hingga usia 24 bulan turun dari $79 \%$ menjadi $52 \%$, sedangkan penggunaan susu formula naik tiga kali lipat. Selain melalui iklan di media dan promosi di pertokoan, para produsen susu formula juga aktif berpromosi di rumah sakit serta melalui tenaga pelayanan kesehatan, seperti dokter. Banyak ibu-ibu yang tidak percaya diri lagi dengan manfaat dari kandungan ASI akibat pengaruh iklan yang mengidealkan kandungan zat gizi terdapat dalam susu formula.

Budaya memberi Air Susu Ibu (ASI) mulai ditinggalkan sehingga menjadi salah satu kendala bagi pemenuhan gizi bagi anak. Ibu-ibu sekarang merasa lebih terhormat jika membelikan anaknya susu formula. Harga susu formula yang mahal membuat mereka bangga ketika membelikan anakanak mereka susu formula, mereka juga bangga bisa disebut sebagai orang kaya yang mampu membeli susu formula dengan harga yang mahal, padahal kandungan yang ada tidaklah sebaik ASI. Ibu berpikir susu formula sama kandunganya dengan ASI bahkan ada ibu yang menganggap susu formula lebih baik dari ASI, ibu-ibu mengatakan susu formula lebih praktis dan mudah penyajianya, ibu takut bayi mereka 
kurang gizi, dan ibu juga merasa takut anaknya menjadi manja dan tidak mandiri serta ada beberapa suami yang melarang istrinya untuk menyusui karena menambah pekerjaan. ${ }^{1}$

Jumlah ibu menyusui menurut data Bidang Pemberdayaan Kesehatan Masyarakat Provinsi Jambi tahun 2011 sebanyak 11.817 orang, dari jumlah tesebut sebesar $1.034 \quad(8,75 \%)$ bayi mendapatkan ASI secara baik sedangkan sisanya $10.783 \quad(91,25 \%)$ tidak mendapatkan ASI secara baik. Angka tersebut masih dibawah cakupan pemberian ASI untuk Kota Jambi. Data lengkap mengenai pemberian ASI eksklusif di Puskesmas dalam Kota Jambi Kecamatan Jambi Selatan berdasarkan data Dinas Kesehatan Kota Jambi tahun 2014 meliputi Puskesmas Pakuan Baru 675 bayi dan yang diberi ASI ekslusif 19 bayi $(2,81 \%)$, Puskesmas Talang Bakung jumlah bayi 481 yang diberi ASI ekslusif 69 bayi (14,35\%), Puskesmas Kebun Kopi jumlah bayi 442 yang diberi ASI ekslusif 46 (10,41\%), Puskesmas Paal Merah I jumlah bayi 440 yang diberi ASI ekslusif $36(8,18 \%)$ dan Puskesmas Paal Merah II jumlah bayi 341 dan yang di beri ASI ekslusif 1 $(0,29){ }^{6}$

Dari data diatas dapat diketahui bahwa tidak ada Puskesmas yang dapat mencapai target dalam melaksanakan program ASI eksklusif. Bahkan ada beberapa Puskesmas yang tidak mempunyai data tentang pemberian ASI eksklusif. Selanjutnya jika dilihat dari besarnya angka pencapaian, maka Puskesmas Aur Duri memiliki angka tertinggi dan Puskesmas Paal Merah II memiliki angka terendah. Puskesmas Koni menduduki peringkat terendah kedua setelah Puskesmas Paal Merah II, jika dilihat dari jumlah bayi maka Puskesmas Tanjung Pinang memiliki jumlah bayi yang banyak dengan pencapaian ASI Eksklusif 4,37 \%.

Berdasarkan latar belakang yang telah di uraian diatas maka penulis tertarik untuk melakukan penelitian mengenai hubungan pengetahuan, dan motivasi ibu dengan pemberian ASI Ekslusif di Kelurahan Palmerah wilayah kerja Puskesmas Paal Merah II Kota Jambi.

\section{METODE PENELITIAN}

\begin{tabular}{ccr}
\multicolumn{2}{c}{ Penelitian ini merupakan } \\
penelitian kuantitatif & dengan
\end{tabular} menggunakan pendekatan prospective yaitu rancang bangun dengan melihat kedepan dari suatu kejadian yang berhubungan dengan kejadian yang diteliti atau kejadian yang terjadinya pada waktu yang bersamaan. Adapun cara pengambilan sampel dalam penelitian ini adalah dengan menggunakan teknik accidental sampling. Peneliti memberi hak yang sama kepada setiap subjek untuk memperoleh kesempatan menjadi sampel

\section{HASIL DAN PEMBAHASAN}

1. Gambaran pengetahuan ibu tentang pemberian ASI di Kelurahan Palmerah wilayah kerja Puskesmas Paalmerah II Kota Jambi

\begin{tabular}{llcc}
$\begin{array}{l}\text { Tabel.1 } \\
\text { berdasarkan }\end{array}$ & $\begin{array}{c}\text { Distribusi } \\
\text { Pengetahuan }\end{array}$ & $\begin{array}{r}\text { Responden } \\
\text { Pemberian ASI Di Kelurahan }\end{array}$ & Tentang \\
\hline No & Pengetahuan & Frekuensi & $\%$ \\
& & & \\
\hline 1 & Tinggi & 35 & 77,8 \\
2 & Rendah & 10 & 22,2 \\
\hline & Total & 45 & 100 \\
\hline
\end{tabular}

Berdasarkan tabel diatas diketahui bahwa pengetahuan responden tentang Pemberian ASI, 10 responden $(22,2 \%)$ memiliki pengetahuan rendah, sedangkan 35 responden $(77,8 \%)$ memiliki pengetahuan tinggi. Berdasarkan hasil penelitian ini diketahui bahwa responden yang 
memiliki pengetahuan tinggi $(77,8 \%)$ lebih banyak dari responden yang memiliki pengetahuan rendah $(22,2 \%)$.

Hasil analisis jawaban dari 45 responden menunjukkan bahwa 44 responden $\quad(97,8 \%) \quad$ frekuensi memberikan ASI pada bayi sudah tinggi, dan semua responden $(100 \%)$ sudah tahu alasan memberikan ASI pada bayi. Akan tetapi masih ada 19 responden $(42,2 \%)$ yang belum tahu faktor yang mempengaruhi produksi ASI, ada 16 responden $(35,6 \%)$ tidak tahu bahwa ASI pertama yang keluar dari payudara ibu mengandung gizi yang banyak, selengkapnya dapat dilihat pada tabel berikut ini:

Tabel 2 Distribusi Pengetahuan Responden tentang Pemberian ASI di Kelurahan Palmerah Wilayah Kerja Puskesmas Paal Merah II

\begin{tabular}{|c|c|c|c|c|}
\hline \multirow{3}{*}{ PERNYATAAN } & \multicolumn{4}{|c|}{ Distribusi } \\
\hline & \multicolumn{2}{|c|}{ Tahu } & \multicolumn{2}{|c|}{$\begin{array}{l}\text { Tidak } \\
\text { Tahu }\end{array}$} \\
\hline & $\mathbf{F}$ & $\%$ & $\mathbf{F}$ & $\%$ \\
\hline $\begin{array}{l}\text { Waktu ibu mulai } \\
\text { memberikan ASI }\end{array}$ & 41 & $\begin{array}{l}91 \\
.1\end{array}$ & 4 & 8.9 \\
\hline $\begin{array}{l}\text { Frekuensi } \\
\text { memberikan ASI } \\
\text { pada bayi ibu }\end{array}$ & 44 & $\begin{array}{l}97 \\
.8\end{array}$ & 1 & 2.2 \\
\hline $\begin{array}{l}\text { Alasan ibu } \\
\text { memberikan ASI }\end{array}$ & 45 & $\begin{array}{l}10 \\
0\end{array}$ & 0 & 0 \\
\hline $\begin{array}{l}\text { Yang dimaksud } \\
\text { dengan ASI }\end{array}$ & 40 & $\begin{array}{c}88 \\
.9\end{array}$ & 5 & 11.1 \\
\hline $\begin{array}{l}\text { Manfaat } \\
\text { pemberian ASI }\end{array}$ & 45 & $\begin{array}{l}10 \\
0\end{array}$ & 0 & 0 \\
\hline $\begin{array}{l}\text { Faktor yang } \\
\text { mempengaruhi } \\
\text { produksi ASI }\end{array}$ & 26 & $\begin{array}{l}51 \\
.1\end{array}$ & 19 & 48.9 \\
\hline $\begin{array}{l}\text { ASI } \\
\text { mempengaruhi } \\
\text { pertumbuhan dan } \\
\text { perkembangan } \\
\text { bayi }\end{array}$ & 43 & $\begin{array}{l}95 \\
.6\end{array}$ & 2 & 4.4 \\
\hline
\end{tabular}

\begin{tabular}{lccc|c}
\hline & \multicolumn{4}{c}{ Distribusi } \\
\cline { 2 - 5 } PERNYATAAN & \multicolumn{2}{c}{ Tahu } & \multicolumn{2}{c}{$\begin{array}{c}\text { Tidak } \\
\text { Tahu }\end{array}$} \\
\cline { 2 - 5 } & F & \% & F & \% \\
\hline $\begin{array}{l}\text { ASI pertama yang } \\
\text { keluar dari } \\
\text { payudara ibu }\end{array}$ & 29 & 64 & 16 & 35.6 \\
mengandung gizi & & .4 & & \\
yang banyak & & & & \\
$\begin{array}{l}\text { Pemberian ASI } \\
\text { dini } \\
\text { mempengaruhi }\end{array}$ & 35 & 77 & 10 & 22.2 \\
pertumbuhan dan & & .8 & & \\
perkembangan & & & & \\
bayi & & & & \\
\hline $\begin{array}{l}\text { Kapan sebaiknya } \\
\text { bayi baru lahir } \\
\text { diberi ASI pertama } \\
\text { kali }\end{array}$ & 42 & 93 & 3 & 6.7 \\
\hline
\end{tabular}

2. Gambaran motivasi ibu dalam pemberian ASI di Kelurahan Palmerah wilayah kerja Puskesmas Paalmerah II Kota Jambi

Tabel 3. Distribusi Responden Berdasarkan Motivasi Terhadap Pemberian ASI di Kelurahan Palmerah wilayah kerja Puskesmas Paalmerah II

\begin{tabular}{clcc}
\hline No & Motivasi & Frekuensi & $\%$ \\
\hline 1 & Baik & 37 & 82,2 \\
2 & Kurang Baik & 8 & 17,8 \\
& Total & 43 & 100,0 \\
\hline
\end{tabular}

Berdasarkan tabel diatas diketahui bahwa motivasi terhadap pemberian ASI, 8 responden $(17,8 \%)$ memiliki motivasi kurang baik, sedangkan 37 responden $(82,2 \%)$ memiliki motivasi baik.

Tabel 4. Distribusi Frekuensi Jawaban Responden Tentang Motivasi Pemberian ASI di Kelurahan Palmerah wilayah kerja Puskesmas Paalmerah II 


\begin{tabular}{|c|c|c|c|c|}
\hline \multirow{3}{*}{ PERNYATAAN } & \multicolumn{4}{|c|}{ Distribusi } \\
\hline & \multicolumn{2}{|c|}{$\mathbf{Y a}$} & \multicolumn{2}{|c|}{ Tidak } \\
\hline & $\mathbf{F}$ & $\%$ & $\mathbf{F}$ & $\%$ \\
\hline $\begin{array}{l}\text { Ibu telah berencana } \\
\text { untuk memberikan } \\
\text { ASI }\end{array}$ & 26 & 57.8 & 19 & $\begin{array}{c}42 . \\
2\end{array}$ \\
\hline $\begin{array}{l}\text { Ibu wajib } \\
\text { memberikan ASI } \\
\text { secara dini pada } \\
\text { bayi }\end{array}$ & 43 & 95.6 & 2 & 4.4 \\
\hline $\begin{array}{l}\text { Ibu pemberian ASI } \\
\text { secara dini adalah } \\
\text { makanan terbaik }\end{array}$ & 44 & 97.8 & 1 & 2.2 \\
\hline $\begin{array}{l}\text { Suami } \\
\text { menganjurkan ibu } \\
\text { untuk memberikan } \\
\text { ASI }\end{array}$ & 42 & 93.3 & 3 & 6.7 \\
\hline $\begin{array}{l}\text { Suami memberikan } \\
\text { dukungan agar ibu } \\
\text { memberikan ASI }\end{array}$ & 41 & 91.1 & 4 & 8.9 \\
\hline $\begin{array}{l}\text { Saran dari petugas } \\
\text { kesehatan agar ibu } \\
\text { memberikan ASI }\end{array}$ & 40 & 88.9 & 5 & $\begin{array}{c}11 . \\
1\end{array}$ \\
\hline $\begin{array}{l}\text { Ibu pernah } \\
\text { menanyakan } \\
\text { tentang manfaat } \\
\text { ASI pada petugas } \\
\text { kesehatan }\end{array}$ & 14 & 31.1 & 31 & $\begin{array}{c}68 . \\
9\end{array}$ \\
\hline $\begin{array}{l}\text { Ibu memberikan } \\
\text { ASI setiap bayi } \\
\text { membutuhkan dan } \\
\text { tidak tergantung } \\
\text { waktu untuk } \\
\text { memberikan }\end{array}$ & 41 & 91.1 & 4 & 8.9 \\
\hline $\begin{array}{l}\text { Ibu yakin dengan } \\
\text { memberikan ASI } \\
\text { akan dapat } \\
\text { membentuk bayi } \\
\text { yang sehat dan } \\
\text { cerdas }\end{array}$ & 39 & 86.7 & 6 & $\begin{array}{c}13 . \\
3\end{array}$ \\
\hline $\begin{array}{l}\text { Ibu tidak takut } \\
\text { dengan perubahan } \\
\text { yang terjadi pada } \\
\text { tubuh ibu apabila } \\
\text { memberikan ASI }\end{array}$ & 41 & $\begin{array}{c}91 . \\
1\end{array}$ & 4 & 8.9 \\
\hline
\end{tabular}

Tabel 5. Distribusi Responden Berdasarkan pemberian ASI di Kelurahan Palmerah Wilayah Kerja Puskesmas Paalmerah II

\begin{tabular}{clcc}
\hline No & $\begin{array}{c}\text { Pemberian } \\
\text { ASI }\end{array}$ & Frekuensi & Persentase \\
\hline 1 & Baik & 28 & 62,2 \\
2 & Kurang & 17 & 37,8 \\
& Baik & & \\
& Total & 45 & 100 \\
\hline
\end{tabular}

Berdasarkan hasil penelitian ini diketahui bahwa responden yang memberikan ASI secara baik $(62,2 \%)$ lebih banyak dari responden yang memberikan ASI secara kurang baik $(37,8 \%)$.

Berdasarkan jawaban responden diketahui bahwa frekuensi pemberian ASI sudah baik dan responden mengetahui alasan dan manfaat pemberian ASI kepada bayi. Akan tetapi masih ada responden yang belum tahu faktor yang mempengaruhi produksi ASI dan ada responden yang tidak tahu bahwa ASI pertama yang keluar dari payudara ibu mengandung gizi yang banyak.

Hasil penelitian ini didukung oleh teori yang dikemukakan oleh Notoatmodjo $^{7}$, pengetahuan merupakan hasil dari tahu, dan ini terjadi setelah orang melakukan penginderaan terhadap satu objek tertentu. Penginderaan terjadi melalui panca indera manusia yakni indera penglihatan, pendengaran, penciuman, rasa, dan raba. Sebagian besar pengetahuan manusia diperoleh melalui mata dan telinga. Dari pengalaman dan penelitian terbukti bahwa perilaku yang didasari oleh pengetahuan akan lebih lama dari pada perilaku yang tidak didasari oleh pengetahuan.

Sedangkan berdasarkan frekuensi jawaban responden menunjukkan bahwa responden memiliki motivasi tinggi dengan mengetahui pemberian ASI secara dini adalah makanan terbaik dan responden memiliki motivasi tinggi dengan menyatakan ibu wajib memberikan ASI secara dini pada bayi, tetapi masih ada responden yang tidak memiliki rencana menyusui sewaktu masih hamil dan responden tidak menanyakan tentang manfaat ASI kepada petugas kesehatan.

Hasil penelitian ini didukung oleh teori yang dikemukakan oleh Notoatmodjo $^{8}$, motivasi atau dorongan 
adalah rangsangan yang kuat terhadap organisme (manusia) untuk bertingkah laku seperti lapar, haus, seks, kejenuhan dan sebagainya. Rangsangan ini disebut dorongan primer yang menjadi dasar utama untuk motivasi. Menurut Miller dan Dollard, semua tingkah laku (termasuk tingkah laku tiruan) didasari oleh dorongan-dorongan primer ini.

Hubungan pengetahuan responden tentang pemberian ASI Kelurahan Palmerah wilayah kerja Puskesmas Paalmerah II Kota Jambi

Tabel 6 Hubungan Pengetahuan Responden terhadap Pemberian ASI di Kelurahan Palmerah Wilayah Kerja Puskesmas Paalmerah II Kota Jambi

\begin{tabular}{|c|c|c|c|c|c|c|c|}
\hline \multirow{3}{*}{$\begin{array}{l}\text { Pengetah } \\
\text { uan }\end{array}$} & \multicolumn{4}{|c|}{ Pemberian ASI } & \multirow{2}{*}{\multicolumn{2}{|c|}{ Jumlah }} & \multirow{3}{*}{$\begin{array}{l}\mathrm{P} . \\
\mathrm{V}\end{array}$} \\
\hline & \multicolumn{2}{|c|}{$\begin{array}{c}\text { Kurang } \\
\text { Baik }\end{array}$} & \multicolumn{2}{|c|}{ Baik } & & & \\
\hline & $\mathrm{Jlh}$ & $\%$ & $\mathrm{Jlh}$ & $\%$ & $\begin{array}{l}\mathrm{J} 1 \\
\mathrm{~h}\end{array}$ & $\%$ & \\
\hline Rendah & 7 & 70 & 3 & 30 & 10 & 10 & \\
\hline Tinggi & 10 & $\begin{array}{c}28 . \\
6\end{array}$ & 25 & $\begin{array}{c}71 . \\
4\end{array}$ & 35 & $\begin{array}{c}10 \\
0\end{array}$ & $\begin{array}{l}0, \\
0\end{array}$ \\
\hline Total & 17 & $\begin{array}{c}37, \\
8\end{array}$ & 38 & $\begin{array}{c}62 . \\
2\end{array}$ & 45 & $\begin{array}{c}10 \\
0\end{array}$ & 4 \\
\hline
\end{tabular}

Pengetahuan responden yang baik tentang ASI ternyata berdampak baik dengan pemberian ASI. Namun responden dalam frekuensi pemberian ASI yang tidak terlalu sering sehingga dapat mengakibatkan bayi merasa kurang mendapatkan ASI yang cukup, kemudian dapat diduga bahwa ASI yang dihasilkan oleh ibu tidak terlalu banyak.

Pengetahuan responden tentang ASI dapat langsung memberikan pemahaman yang sama sehingga ibu harus melakukanya. Pemberian ASI tergantung dari keadaan ibu, lingkungan dan dukungan keluarga serta keadaan patologi persalinan yang dialami, selanjutnya banyak ibu memiliki pengertian yang berbeda-beda tentang pemberian ASI, sehingga dapat menimbulkan pemahaman yang berbeda pula. Karena memahami adalah suatu kemampuan untuk menjelaskan secara benar tentang materi yang diketahui dan dapat menginterprestasikan secara benar.

Rendahnya cakupan pemberian ASI sudah menjadi masalah Nasional, ternyata tidak disebabkan oleh pengetahuan ibu tentang pemberian ASI yang kurang baik, tetapi diperkirakan banyak faktor yang menjadi penyebab rendahnya cakupan ASI tersebut, antara lain dapat disebabkan oleh faktor ibu itu sendiri seperti ibu yang bekerja, keadaan gizi ibu, pengaruh budaya, dan kebiasaan dalam keluarga, sehingga mempengaruhi dalam pemberikan ASI. Dalam penelitian ini masih ada responden yang memberikan ASI $\leq 6$ bulan. Keadaan gizi ibu menyusui juga menjadi salah satu penyebab, dimana ibu yang memiliki gizi yang kurang akan menghasilkan ASI yang sedikit. Gizi ibu menyusui sangat penting untuk memperbanyak produksi ASI.

Pada penelitian ini masih banyak ibu yang memberikan ASI hanya 4-5 kali sehari, hal tersebut menunjukkan bahwa produksi ASI ibu sedikit dan tidak mencukupi kebutuhan bayi. Beberapa upaya yang dapat dilakukan untuk meningkatkan cakupan ibu tentang pemberian ASI adalah dengan memberikan pendidikan kesehatan antara lain penyuluhan, informasi tentang pengertian pemberian ASI, tujuan, lama pemberian ASI, manfaat pemberian ASI, akibat pemberian susu formula khususnya pada saat awal persalinan melalui penyuluhan, poster, leaflet ataupun pada saat tertentu pemutaran film atau CD.

Hubungan motivasi responden tentang pemberian ASI di Kelurahan Palmerah 
wilayah kerja Puskesmas Paalmerah II Kota Jambi

Tabel 7.Hubungan Motivasi Responden terhadap pemberian ASI di Kelurahan Palmerah

\begin{tabular}{|c|c|c|c|c|c|c|c|}
\hline \multirow{3}{*}{ Motivasi } & \multicolumn{4}{|c|}{ Pemberian ASI } & \multirow{2}{*}{\multicolumn{2}{|c|}{ Jumlah }} & \\
\hline & \multicolumn{2}{|c|}{$\begin{array}{c}\text { Kurang } \\
\text { Baik }\end{array}$} & \multicolumn{2}{|c|}{ Baik } & & & \\
\hline & Jlh & $\%$ & $\mathrm{Jlh}$ & $\%$ & Jlh & $\%$ & \\
\hline Kurang & 6 & 75.0 & 2 & 25.0 & 8 & 100 & 0. \\
\hline Baik & 11 & 29.7 & 26 & 70.3 & 37 & 100 & 0 \\
\hline Baik & & & & & & & 4 \\
\hline Total & 17 & 37.8 & 28 & 62.2 & 45 & 100 & 6 \\
\hline
\end{tabular}

Berdasarkan hasil penelitian terhadap 45 responden diketahui bahwa dari 8 responden yang memiliki motivasi kurang baik, sebanyak 6 responden (75.0\%) memiliki motivasi kurang baik dan 2 responden $(25,0 \%)$ memiliki motivasi baik tentang pemberian ASI, sedangkan dari 37 responden yang memiliki motivasi baik, sebanyak 26 responden $(70,3 \%)$ baik dalam pemberian ASI dan sebanyak 11 responden $(29,7 \%)$ yang kurang baik dalam memberikan ASI. Analisis statistik menunjukkan nilai p-value $(0,046)<\mathrm{r}$ tabel $(0,05)$ sehingga disimpulkan terdapat hubungan bermakna antara motivasi responden terhadap pemberian ASI.

Motivasi yang baik dan terus menerus dapat memberikan pengaruh bagi tercapainya peningkatan jumlah pemberian ASI. Motivasi bisa datang dari dalam diri dengan membaca, menonton televisi dan mendengarkan pengalaman orang lain. Motivasi dari suami, keluarga dan petugas kesehatan memegang peranan yang sangat penting terhadap pencapaian pemberian ASI. Motivasi yang baik diharapkan dapat membantu responden dalam mencapai pemberian cakupan ASI yang baik yang sesuai harapan, motivasi yang baik juga diharapkan mampu untuk mengatasi halhal yang mempengaruhi penurunan pemberian ASI. Adapun beberapa hal yang dapat mempengaruhi penurunan pemberian ASI, salah satunya dengan gencarnya promosi susu formula menjadi penyebab menurunnya jumlah bayi yang mendapatkan ASI.

Motivasi menurut Notoatmodjo, ${ }^{6}$ merupakan kekuatan dorongan yang menggerakan kita untuk berprilaku tertentu. Motivasi akan berhubungan dengan hasrat, keinginan, dorongan dan tujuan, selanjutnya masih menurut Notoatmodjo motivasi adalah interaksi antara perlakuan dan lingkungan sehingga dapat meningkatkan, menurunkan atau mempertahankan perilaku. Motivasi untuk memberikan ASI merupakan dorongan, anjuran, dan keputusan untuk memberikan ASI.

Usaha untuk meningkatkan jumlah pencapaian ASI sebesar $80 \%$ pada tahun 2011 adalah dengan meningkatkan motivasi kepada ibu dan calon ibu sejak dini, serta meningkatkan peran serta dari petugas konseling yang ada di tiap Puskesmas dan mengurangi promosi susu formula. Motivator konseling harus dapat meningkatkan pengetahuannya menjadi konselor bukan hanya sebagai motivator, karena dengan begitu kebutuhan klien akan dapat teratasi jika menemukan masalah berkaitan dengan pemberian ASI.

\section{SIMPULAN}

Berdasarkan uraian dari hasil penelitian dan pembahasan tentang hubungan pengetahuan, dan motivasi tentang pemberian ASI di Kelurahan Palmerah Wilayah Kerja Puskesmas Paalmerah II Kota Jambi, maka dapat dikemukakan beberapa kesimpulan Pengetahuan responden tentang pemberian ASI yang memiliki pengetahuan tinggi yaitu sebanyak 35 responden $(77,8 \%)$ dan Motivasi terhadap pemberian ASI yang memiliki motivasi yang baik yaitu sebanyak 37 responden $(82,2 \%)$. Pemberian ASI baik 
yaitu sebanyak 28 responden $(62,2 \%)$. Ada hubungannya antara pengetahuan dengan pemberian ASI di Kelurahan Palmerah wilayah kerja Puskesmas Paalmerah II Kota Jambi, dengan nilai $p$ value sebesar 0,044 . Ada hubungannya antara motivasi dengan pemberian ASI di Kelurahan Palmerah wilayah kerja Puskesmas Paalmerah II Kota Jambi, dengan nilai $p$-value sebesar 0,046 .

\section{SARAN}

Sebagai bahan masukan dan informasi guna menyusun langkahlangkah konkrit untuk meningkatkan upaya memberian ASI utamanya pemberian ASI secara Eksklusif dalam upaya meningkatkan cakupan pemberian ASI eksklusif yang telah ditetapkan secara Nasional.

\section{DAFTAR PUSTAKA}

1. Muchtadin, 2002. Kesehatan Ibu dan Anak. Penerbit Rineka Cipta Jakarta

2. Bahiyatun, 2009. ASI Makana Baik Bayi. Yogyakarta.

3. Ukhti, 2008. Bangsa Kurang Gizi. Dreamlandaulah. Jakarta.

4. Kompas, 2009. Pencegahan Kematian Dengan Pemberian ASI. Koran Independen. Jakarta

5. Dinkes Provinsi Jambi, 2010. Provil Jambi 2010. Jambi.

6. Notoatmodjo, Soekitjo, 2003. Ilmu Kesehatan Masyarakat. Penerbit Rineka Cipta. Jakarta

7. Suririnah. 2009. Buku Pintar Merawat Bayi O -12 bulan. Penerbit PT. Gramedia Pustaka Utama. Jakarta.

8. Afifah, Nurdiana. 2004. Baru $2 \%$ Ibu Memberikan ASI Eksklusif.

9. Arif, Nurhaeni. 2009. ASI dan Tumbuh Kembang Bayi. Penerbit Media Pressindo. Yogyakarta.

10. Arikunto, Suharsimi. 2006. Prosedur Penelitian Suatu Pendekatan Praktik. Penerbit Rineka Cipta. Jakarta. 